\title{
Growth and Sporulation Physiology of Postharvest Pathogen Thielaviopsis paradoxa (De Seynes.) Höhn
}

\author{
Niren Majumdar* and Nakul Chandra Mandal \\ Department of Plant Protection, Palli-Siksha Bhavana (Institute of Agriculture), \\ Visva-Bharati, Sriniketan-731236, Birbhum, West Bengal, India \\ *Corresponding author
}

\section{A B S T R A C T}

\section{Keywords \\ Growth, \\ Sporulation, Media, $\mathrm{pH}$, Temperature, \\ Thielaviopsis paradoxa \\ Article Info \\ Accepted: \\ 06 June 2018 \\ Available Online: \\ 10 July 2018}

\begin{abstract}
Thielaviopsis paradoxa is an ascomyceteous fast growing fungus has broad host range under tropical condition. The growth dynamics and sporulation of this pathogen have been investigated in relation to various media, physical factors like temperature and $\mathrm{pH}$ with significant variation among the treatments. All 12 media supported growth although with a change in their dynamics. Maximum radial growth were recorded on PDA, PSA, MEA and OMA media and the optimum temperature for growth was $30^{\circ} \mathrm{C}$ although the cardinal temperatures were $10^{\circ} \mathrm{C}$ and $40^{\circ} \mathrm{C}$. No growth was found on PDA at temperature $40^{\circ} \mathrm{C}$ and very scanty growth at $10^{\circ} \mathrm{C}$, after $96 \mathrm{hrs}$ of incubation. Optimum $\mathrm{pH}$ for growth was 5.0 and 6.0. Least growth recorded both on $\mathrm{CDA}$ medium and at $\mathrm{pH}$ of 9.0. Highest sporulation recorded on OMA medium and temperature at $30^{\circ} \mathrm{C}$ and $\mathrm{pH} 6.0$ on PDA whereas lowest sporulation found at $\mathrm{pH} 8.0$ on PDA and on CDA medium.
\end{abstract}

\section{Introduction}

Thielaviopsis paradoxa is an important postharvest fungal pathogen, which was encountered to cause enormous economical loss to different fruits both in transit and storage. Generally, it is a soil inhabiting fungus, yet it has the capacity to affect various parts of the plant as a wound parasite (Py et al., 1987) .In pineapple, three distinct phases leaf spot, bud rot and fruit rot have been recognized and Cho et al, (1977) found that it severely affects both buds and fruits as bud rot and fruit rot diseases, respectively as compared to leaf spot infections. The fruit rot phase of pineapple was variously named and recognized as black rot, soft rot, stem end rot or water blister and this became serious at the postharvest phase with worldwide distribution (Ploetz, 2003) limiting long distance transport or long term storage. It is a polyphagous fungus (Frossard, 1968) and the major hosts include pineapple, corn, sorghum, sugarcane, cocoa, date palm, banana and sweet potato. In the postharvest state it was also obtained from guava, pear, chilli, potato bean tuber (Mandal, 1981) and musk melon (Rao and subramaniam, 1975). Thielaviopsis paradoxa 
causing blight in mango in Brazil (Piza,1966; Ribiero,1980). Research conducted on artificial inoculation by different isolates obtained by many other authors suggest isolates are cross inoculable and produce various kinds of effects like seedling decay following planting causing poor stand in sugar cane (Bautista,2014). Black scorch of date palm is long known (Klotaz, 1932). Because of its faster growth rate and as a wound pathogen it has considerable potential for damage. Although the growth and extent of rotting are greater in mature banana fruit, it can invade stem tissue and green fruit as well. When rot occur in harvested ripe or near ripe fruit, the invaded flesh become soft and water soaked (Kader, 2002). In India including West Bengal, T. paradoxa affecting mango has not been recorded earlier under natural condition although cross inoculability of both sugarcane and arecanut isolates to mango has been reported.(Sundararaman,1928; Sundararaman et al., 1928).

The anamorph state $T$. paradoxa is much common with abundant matured (brown coloured) and immature (hyaline) conidial production however, the teleomorph state Ceratocystis paradoxa (Dade)Moreau with ascospore is available in natural state under Indian condition. The physiology of growth and sporulation of $T$. paradoxa have not been investigated in details.

\section{Materials and Methods \\ Isolation and Identification of pathogen}

Naturally infected fruits were collected from the orchard of University farm, Palli-Siksha Bhavana, Visva Bharati $\left(23.6693^{\circ} \mathrm{N}, 87.6593^{\circ}\right.$ E). Isolation of fungi was performed by standard surface sterilization method followed by incubation on PDA at $25 \pm 1^{\circ} \mathrm{C}$ for 24 hours. The fungal colonies that appeared on the PDA surface surrounding infected fruit bits after incubation period were aseptically transferred on fresh sterilized petri plates containing PDA. Isolates from a single colony were maintained for further studies including identification with the help of standard literature (Ellis, 1971).

\section{Effect of selective nutrient media on $T$. paradoxa}

The cultural characters of $T$. paradoxa were examined on different agar media namely PDA (Potato Dextrose Agar), PCA(Potato carrot Agar), PSA(Potato Sucrose Agar), OMA(Oat Meal Agar),MEA(Malt Extract Agar),YDA(Yeast Extract Dextrose Agar), GPA(Glucose Peptone Agar), MPDA (Malt Extract Peptone Dextrose Agar), RA (Richard's Agar), SA(Sabouraud's Agar),CDA (Czapek dox Agar),WA(Water Agar) which were prepared as standard methods and composition. The composition of different media mentioned above is available in Dhingra and Sinclair, 2012. After that $5 \mathrm{~mm}$ disc from $T$. paradoxa culture was cut by using a sterilized cork borer and a single disc was placed at the centre of cool sterilized petri plate containing media. Each set of experiment was replicated thrice and the plates were incubated at $28 \pm 1^{\circ} \mathrm{C}$ for 5 (five) days. The cultural characters such as colony diameter, colour, type of margin, aerial growth were recorded.

\section{Effect of pH levels on physiology of T.paradoxa}

Potato dextrose Agar (PDA) was prepared by standard method and in order to avoid bacterial contamination $0.05 \mathrm{~g}$ of chloramphenicol per litre were added to the medium. The prepared unsterilized medium was distributed within $100 \mathrm{ml}$ conical flasks at the rate of $50 \mathrm{ml}$ per flask. The required $\mathrm{pH}$ was adjusted either by adding Hydrochloric acid $(0.1 \mathrm{HCl})$ or Sodium hydroxide $(0.1 \mathrm{~N}$ 
$\mathrm{NaOH})$ solution. In order to stabilize the $\mathrm{pH}$, $20 \%$ phosphate buffer was used. Six pH treatment levels 4.0, 5.0, 6.0, 7.0, 8.0, and 9.0 were maintained and replicated thrice. The final $\mathrm{pH}$ was measured using electrical $\mathrm{pH}$ meter before sterilization within autoclave at $121^{\circ} \mathrm{C}$. Prepared media was immediately used for growth studies of the fungi. Optimum $\mathrm{pH}$ was determined by measuring fungal mycelial growth (mm).

\section{Effect of various temperature levels on T.paradoxa}

Sterilized media poured into the petriplates @ $20 \mathrm{ml}$ per plate was inoculated with 7days old culture of T.paradoxa and kept at temperature levels viz., $10,15,20,25,30,35$ and $40^{\circ} \mathrm{C}$ for fungal colony development and three replications were maintained for each treatment. Most suitable temperature for T.paradoxa was determined by measuring mycelial growth $(\mathrm{mm})$.

\section{Statistical analysis}

Data obtained were analysed using one way Analysis of Variance (ANOVA) using the SPAR 3.0 for data analysis.

\section{Results and Discussion}

Determination of mycelial growth of T.paradoxa under different media

Fungal growth alongwith its certain morphological characters are highly influenced on the composition of the various types of media used by the researchers. The preferential uptake of nutrients is strongly determined not only by the qualitative aspects but also the kind and quantitative nutritional values. Isolate from a host either may or may not be media specific. In case of $T$. paradoxa, sugarcane isolate can infect mango, banana, date palm and other Saccharum
sp.(Sundararaman,1928) but media specificity was not determined. The growth of T.paradoxa was found to be influenced by all 12 media tested and data are presented in Table 1 and 2. The data of the experiment presented in Table 1 revealed that mycelia growth substantially differ between scanty and fluffy. While media like PCA, SA, RA and WA support only scanty growth, on the other hand PDA, PSA, MEA and OMA media results in luxuriant and profuse growth. The moderate growth was obtained on YDA, MPDA and GPA media. The amount of available energy source (sugar) perhaps played significant contribution on the mycelial growth (Griffin, 1994). Therefore, for initial isolation and to avoid contamination the most common media PDA can be used. Since T.paradoxa is a very fast growing fungus the colony diameter was attained maximum within 72 hours of incubation incase of PDA, PSA, YDA and MPDA although extremely poor radial growth on CDA medium. Similar observation was recorded on CDA medium by Bachiller et al., (1998) in Philippines.

As the colony colour is not a stable character among fungi obviously here too this parameter appeared after 120 hours of incubation was found to be changed among the media used. While light colonies almost white can be recorded on CDA and RA media, on the contrary light blackish (WA) to extremely deep black colonies observed on PDA, PSA, MEA and MPDA. This criterion of deep black coloured colony can be used for selective isolation of this fungus as similar observation of pink colony is common on Fusarium moliniformae on PDA. (Booth, 1971). Inconsistency in colony colour (dull white to light brown) was noted in YDA medium and the reason is not clear (Plate-1). The fungus produce maximum spore in OMA followed by YDA, PSA, PDA and MEA whereas least sporulation was observed on CDA. 
Table.1 Effect of media on morphological character of T.paradoxa

\begin{tabular}{|c|c|c|c|c|}
\hline Media & Mycelial Growth & $\begin{array}{l}\text { Colony } \\
\text { dia(mm) after } \\
\text { 72hours }\end{array}$ & Colony colour & Sporulation \\
\hline PDA & Profuse & 95.00 & Black pigmentation & Very High \\
\hline PCA & Scanty filamentous & 91.00 & $\begin{array}{l}\text { light blackish growth; } \\
\text { pigmentation absent }\end{array}$ & Poor \\
\hline PSA & Profuse growth & 95.00 & $\begin{array}{l}\text { off white to black } \\
\text { pigmentation }\end{array}$ & Good \\
\hline OMA & Fluffy mycelial growth & 83.33 & Brown & heavy \\
\hline MEA & $\begin{array}{l}\text { Smooth growth; advancing } \\
\text { margin regular }\end{array}$ & 90.00 & Deep black & good \\
\hline YDA & $\begin{array}{l}\text { mycelia growth advancing } \\
\text { margin regular }\end{array}$ & 95.00 & Dull white to light brown & heavy \\
\hline GPA & Fluffy mycelial growth & 85.00 & Off white to greyish & medium \\
\hline $\begin{array}{l}\text { MPD } \\
\text { A }\end{array}$ & $\begin{array}{l}\text { Smooth fast growth } \\
\text { advancing margin regular }\end{array}$ & 95.00 & $\begin{array}{l}\text { Deep black in periphery } \\
\text { with dull white centre }\end{array}$ & medium \\
\hline RA & Low fluffy mycelial growth & 21.33 & White mycelial growth & Very poor \\
\hline SA & $\begin{array}{l}\text { Filamentous mycelia } \\
\text { advancing margin irregular }\end{array}$ & 77.83 & light blackish & very poor \\
\hline CDA & smooth slow growth & 15.67 & White & very poor \\
\hline WA & $\begin{array}{l}\text { Scanty, filamentous irregular } \\
\text { advancing margin }\end{array}$ & 60.00 & Dull white growth, & poor \\
\hline
\end{tabular}

Table.2 Effect of media on radial growth and sporulation of T.paradoxa

\begin{tabular}{|l|l|l|l|c|}
\hline Media & $\mathbf{2 4}$ & $\mathbf{4 8}$ & $\mathbf{7 2}$ & $\begin{array}{c}\text { Sporulation per ml } \\
\text { at 120hrs }(\mathbf{x ~ 1 0}\end{array}$ \\
\hline PDA & 26.17 & 95.00 & 95.00 & 6.27 \\
\hline PCA & 12.00 & 51.00 & 91.00 & 0.96 \\
\hline PSA & 23.67 & 84.33 & 95.00 & 7.00 \\
\hline OMA & 20.17 & 70.33 & 83.33 & 8.54 \\
\hline MEA & 19.00 & 66.67 & 90.00 & 5.20 \\
\hline YDA & 18.00 & 81.00 & 95.00 & 7.20 \\
\hline GPA & 11.00 & 51.67 & 85.00 & 2.80 \\
\hline MPDA & 17.00 & 65.33 & 95.00 & 2.60 \\
\hline RA & 0.00 & 8.00 & 21.33 & 0.11 \\
\hline SA & 0.50 & 38.50 & 77.83 & 0.66 \\
\hline CDA & 0.00 & 4.67 & 15.67 & 0.07 \\
\hline WA & 1.17 & 28.50 & 60.00 & 0.21 \\
\hline SEm & 0.68 & 0.94 & 1.40 & 0.61 \\
\hline CD $<\mathbf{0 . 0 5}$ & 1.98 & 2.74 & 4.07 & 1.75 \\
\hline
\end{tabular}


Table.3 Radial growth and sporulation of T.paradoxa at different $\mathrm{pH}$ levels

\begin{tabular}{|c|c|c|c|c|}
\hline pH & 24 & 48 & 72 & $\begin{array}{c}\text { Sporulation per ml at } \\
120 \mathrm{hrs}\left(\times 10^{6}\right)\end{array}$ \\
\hline 4.0 & 33.17 & 89.25 & 91.33 & 4.80 \\
\hline 5.0 & 32.83 & 90.83 & 94.50 & 4.89 \\
\hline 6.0 & 31.08 & 89.25 & 94.17 & 5.24 \\
\hline 7.0 & 29.83 & 82.75 & 90.33 & 4.87 \\
\hline 8.0 & 20.00 & 65.50 & 84.33 & 3.82 \\
\hline 9.0 & 16.00 & 46.92 & 58.83 & 4.40 \\
\hline SEm & 0.60 & 1.11 & 0.96 & 0.22 \\
\hline $\mathrm{CD}<0.05$ & 1.84 & 3.41 & 2.94 & 0.66 \\
\hline
\end{tabular}

Table.4 Effect of temperature on radial growth and sporulation of T. paradoxa

\begin{tabular}{|l|l|l|l|l|l|l|}
\hline Temp $\left({ }^{\mathbf{0}} \mathbf{C}\right)$ & $\mathbf{2 4}$ & $\mathbf{4 8}$ & $\mathbf{7 2}$ & $\mathbf{9 6}$ & $\mathbf{1 2 0}$ & $\begin{array}{l}\text { Sporulation per ml } \\
\mathbf{a t} \mathbf{1 2 0 h r s} \mathbf{( \mathbf { 1 0 }} \mathbf{)}\end{array}$ \\
\hline $\mathbf{1 0}$ & 0.00 & 0.00 & 0.00 & 0.50 & 1.17 & 0.50 \\
\hline $\mathbf{1 5}$ & 2.00 & 18.50 & 43.18 & 69.33 & 84.17 & 2.52 \\
\hline $\mathbf{2 0}$ & 15.83 & 56.17 & 95.00 & 95.00 & 95.00 & 4.27 \\
\hline $\mathbf{2 5}$ & 28.00 & 83.00 & 95.00 & 95.00 & 95.00 & 4.40 \\
\hline $\mathbf{3 0}$ & 27.50 & 84.67 & 95.00 & 95.00 & 95.00 & 5.38 \\
\hline $\mathbf{3 5}$ & 7.33 & 50.67 & 85.00 & 95.00 & 95.00 & 3.69 \\
\hline $\mathbf{4 0}$ & 0.00 & 0.00 & 0.00 & 0.00 & 0.00 & 0.00 \\
\hline $\mathbf{S E m}$ & 0.30 & 0.74 & 0.07 & 0.17 & 0.18 & 0.20 \\
\hline $\mathbf{C D}<\mathbf{0 . 0 5}$ & 0.92 & 2.25 & 0.21 & 0.51 & 0.54 & 0.59 \\
\hline
\end{tabular}

Plate.1 Growth of T. paradoxa on different media (1. PDA, 2.PCA, 3.PSA, 4.OMA, 5.MEA, 6.YDA, 7.GPA, 8.MPDA, 9.RA, 10.SA, 11.CDA, 12.WA)

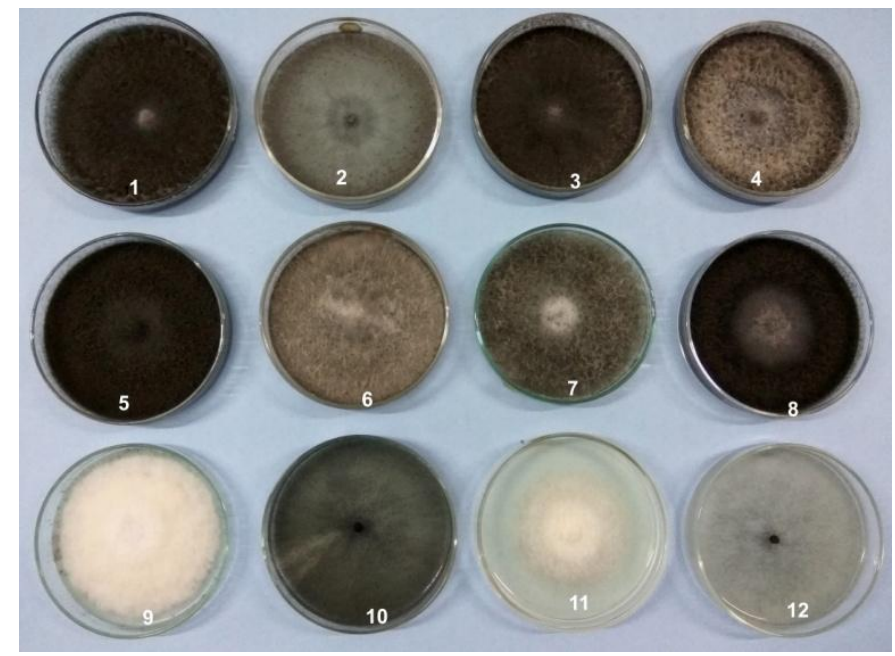


The density of sporulation was not very poor on WA medium despite of the poor nutritional status. Mubarak.et.al.,(1994), have recorded that (T. paradoxa isolate from date palms) sporulation was best on PDA or malt extract agar, among six media tested, at optimum incubation temperature of $30^{\circ} \mathrm{C}$.

Effect of $\mathbf{p H}$ levels on radial growth of T.paradoxa

T.paradoxa growth was observed on various $\mathrm{pH}$ levels on different time intervals as presented in Table 3. After 72 hours of incubation all $\mathrm{pH}$ levels tested were found to support both statistically significant growth and sporulation. Although the best growth was obtained on $\mathrm{pH} 5.0$ and 6.0, However at $\mathrm{pH} 9.0$ the percent reduction of growth was 37.74 as compared to $\mathrm{pH}$ 6.0. Colony colour and the nature of growth were found to be unaffected due to $\mathrm{pH}$ variations used. The trend of growth at different $\mathrm{pH}$ levels was not similar which were found to be declined from 7.0 onwards indicating the fungus is slightly acid loving in nature. Bachiller et al., (1998) also obtained decline in growth and sporulation at $\mathrm{pH} 8.0$ and above. Sporulation was found to be seriously unaffected by different $\mathrm{pH}$ levels tested, although statistically significant.

\section{Effect of various temperature levels on T.paradoxa}

Fungal growth is affected due to variation in temperature of incubation and found to be significant at $95 \%$ confidence level. The mean colony diameter of T.paradoxa on PDA medium was $95.0 \mathrm{~mm}$ at 72 hours of incubation temperature ranges between $20^{\circ} \mathrm{C}$ and at $30^{\circ} \mathrm{C}$, although there were initial variation in growth at 24 and 48 hours. The pathogen did not grow at $40^{\circ} \mathrm{C} \&$ very scanty growth of $1.17 \mathrm{~mm}$ at $10^{\circ} \mathrm{C}$ (Table 4). T.paradoxa grew well in a temperature range of $21-22^{\circ} \mathrm{C}$ and completely inactive below $10^{\circ} \mathrm{C}$ (Agrios, 2005). Mubarak et al., (1994) obtained optimum temperature for germination of conidia of $T$. paradoxa at $25^{\circ} \mathrm{C}-30^{\circ} \mathrm{C}$ and under this temperature regime, the growth was so fast that entire petri plate was covered at $48 \mathrm{hrs}$. The fungus did not sporulate to the extreme temperature of $40^{\circ} \mathrm{C}$ and insignificant at $10^{\circ} \mathrm{C}$. Maximum sporulation observed at temperature of $30^{\circ} \mathrm{C}$ followed by $25^{\circ} \mathrm{C}$ and $20^{\circ} \mathrm{C}$. It has a higher growth rate in culture than most other tropical fruit rotting fungi at optimum temperature and this rate is reduced at $12-14^{\circ} \mathrm{C}$ (Kader, 2002).

Both in India and abroad, effect of temperature, $\mathrm{pH}$ and chemical composition of nutrients on growth and sporulation of different fungi were investigated by many authors. (Dhingra et al., 1979; Prasad and Sinha, 1987; Awadhuya, 1991; Maheshwari et al., 1999; Alam et al., 2001; Rani and Murthy, 2004; Kim et al., 2005; Saha et al., 2008; Gadgile and Chavan, 2010). Therefore, present findings are in agreement with the findings of the earlier workers. The fungus remain found to be extremely viable on PDA medium when sub culturing undertaken after a year of storage at $4^{\circ} \mathrm{C}$.

It is concluded, since growth was obtained best in natural media like PDA, PSA, MEA and OMA could be utilized for both multiplication and any other future studies. The optimum $\mathrm{pH} 5.0$ and 6.0 was found to support best growth and media can be adjusted accordingly. The fungus can be easily cultured at 20 to $30^{\circ} \mathrm{C}$. Both philoconidia and aleuroconidia were produced however abundant aleuroconidia was observed in old cultures. These two types of conidia at anamorph phase were recorded in all 12 media used, $\mathrm{pH} \quad 6.0$ and $30^{\circ} \mathrm{C}$ temperature. In vitro condition none of the media used supported the ascospore production. 


\section{References}

Agrios, G.N. 2005. Plant Pathology. 5th ed. Elsevier

Alam, M.S., M.F. Begum, M.A. Sarkar, M.R. Islam and M.S. Alam. 2001. Effect of temperature, light and media on growth, sporulation, formation of pigments and pycnidia of Botryodiplodia theobromae Pat. Pak. J. Bio. Sci., 4(10): 1224-1227.

Awadhuya G.K.1991. Effect of some cultural factors on growth and spore germination of Alternaria carthami. Journal of Oil Seeds Res., 8(1):123125

Bachiller, N.C.S.J., 1998. Effect of environmental factors on the growth and sporulation of Thielaviopsis paradoxa (de Seynes) Von Hohnel in culture. Philippines Journal of Crop Science, 23: 43.

Bautista-Banos.S.2014.Postharvest decay control strategies. Elsevier Academic press. p290.

Booth.C.1971. The Genus Fusarium. Commonwealth Agricultural Bureaux, England.

Cho, J.J., Rohrbach, K.G. and Apt, W.J. 1977. Induction and chemical control of rot caused by Ceratocystis paradoxa on pineapples. Phytopathology. 67: 700703.

Dhingra OD, Agarwal SC, Khaee, MN and Kushwaha, LS.1979. Temperature requirement of eight strains of Fusarium oxysporum F. Sp. Lentis causing wilt of Lentil. Indian Phytopath, 27:408-410

Dhingra, O.D and Sinclair, J.B.2012. Basic Plant Pathology Methods. $2^{\text {nd }}$ ed. Lewis Publishers.

Ellis, M.B. 1971. Dematiaceous hyphomycetes. Kew, Surrey, England: Commonwealth Mycological Institute.

Frossard, P. 1968. Essais de désinfection des pédoncules d'ananas contre le Thielaviopsis paradoxa. Fruits, apr. 1968, vol. 23, n 4 , p. 207-215.

Gadgile DP and Chavan A M. 2010. Impact of temperature and relative humidity on development of Aspergillus flavus rot of mango fruit. Recent Research in Science \& Technology, 2(3): 48-49

Griffin, H.D.1994. Fungal Physiology. $2^{\text {nd }}$ ed. A John Wiley \&Sons, INC., Publication.pp159

Kader, A.A. 2002. Postharvest Technology of Horticultural crops. University of California Agriculture and Natural Resources. Publication 3529.pp216

Kim YK, Xiao CL, Rogers JD. 2005. Influence of culture media and environmental factors on mycelial growth and pychidial production of Sphaeropsis pyriputrescense. Mycologia, 97:23-25

Klotz,L.J., and Fawcett,H.S. 1932. Black scorch of date palm caused by Thielaviopsis paradoxa. J.Agric. Res. 44: 155-166

Maheshwari SK, Singh DV and Sahu AK. 1999. Effect of several nutrient media, $\mathrm{pH}$ and carbon sources on growth and sporulation of Alternaria alternata. J. Mycopathol. Res. 37:21-23

Mandal,N.C.1981. Postharvest diseases of fruits and vegetables in west Bengal. $\mathrm{PhD}$ dissertation. Visva Bharati, pp 453

Mubarak, H.F., Riaz, M., Saeed, A.I., Hameed, J.A., 1994. Physiological studies and chemical control of black scorch disease of date palm caused by Thielaviopsis paradoxa (Ceratocystis) in Kuwait. Pakistan Journal of Phytopathology, 6: 7-12

Paulin-Mahady, A.E., Harrington, T.C., and McNew, D.L. 2002. Phylogenetic and taxonomic evaluation of Chalara, Chalaropsis, and Thielaviopsis anamorphs associated with 
Ceratocystis. Mycologia 94: 62-72.

Piza, C.de T(ed.).1966 Anais do Simposio Sobre a Seca da Mangueira (Abstracted in Review of applied mycology) 43: 378

Ploetz RC (ed.). 2003. Diseases of tropical fruits crops. Wallingford UK. CABI Publishing.p443

Prasad SS and Sinha AK 1987. In vivo and in vitro production of pectolytic enzymes by Botryodiplodia theobromae and Macrophoma magnifera causing soft rot of mango. Today and Tomorrow's Printers \& Publishers, New Delhi. pp 101-109

Py, C., Lacoeuilhe, J.J. and Teisson, C. 1987. The Pineapple: Cultivation and Uses. G.P. Maisonneuve et Larose, Paris.

Rani SG and Murthy KVMK. 2004. Cultural and Nutritional characteristics of Colletotrichum gloeosporioides, the causal organism in cashewnut anthracnose. J. Mycol. Pl. Path. 34: 317-318

Rao, V.G. and Subramoniam, V. 1975. A new fruit rot of muskmelon. Science and Culture., 41.pp496-497
Ribiero,I.J.A 1980 Seca de Mangueira Agentes causais e studio da molesta.Anais do I simposio Brasiliero Sogre a cultura de Manguiera 24-28 Nov 1980. Sociedad Brasiliera de Furticultura Jaboticobal, Brazil.pp123130

Saha A, Mandal P, Das Gupta.S and Saha.D 2008. Influence of culture media and environmental factors on mycelial growth and sporulation of Lasiodiplodia theobromae (Pat). J. Environ. Biol., 29(3):407-410

Sundararaman, S.1928. Administrative report of the Government Mycologist, Coimbatore for 1926-27. Report Department of Agriculture, Madras Presidency. pp 326-344

Sundararaman, S., Krishnanayar, C and T.S. Ramakrishnana. 1928. The Stem bleeding disease of Areanut (Areca catechu) caused by Thielaviopsis paradoxa Von Hohn. Agri Research Institution, Pusa, Bulletin.169:p12, illus.

\section{How to cite this article:}

Niren Majumdar and Nakul Chandra Mandal. 2018. Growth and Sporulation Physiology of Postharvest Pathogen Thielaviopsis paradoxa (De Seynes.) Höhn. Int.J.Curr.Microbiol.App.Sci. 7(07): 537-544. doi: https://doi.org/10.20546/ijcmas.2018.707.066 